\title{
Bucknill and Casella's Patent Sea-Sounding Apparatus for Navigating Purposes
}

\author{
Lieut. Bucknill R.E.
}

To cite this article: Lieut. Bucknill R.E. (1877) Bucknill and Casella's Patent Sea-Sounding Apparatus for Navigating Purposes, Royal United Services Institution. Journal, 21:91, 821-824, DOI: $10.1080 / 03071847709415817$

To link to this article: http://dx.doi.org/10.1080/03071847709415817

\section{曲 Published online: 11 Sep 2009.}

Submit your article to this journal $\pi$

Џ Article views: 2

Q View related articles $₫$ 


\title{
BUCKATLL AND CASSELLA'S PATENT SEA.SOUNDING APPARATUS FOR NAVIGATING PURPOSES.
}

\author{
By Lieut. Bechisil, R.F.'
}

Ix 1870 , when on board one of H.MI.'s ships, and again in 1872 on one of the Allen Line steamers, the great difficulty in obtaining a reliable deep sea sounding camo under my obserration, and the idea of measuring the depth by means of a pressure gange lorrered with the sounding lead occurred to me.

The first pattern of such an apparatus was made for me by an American firm at Boston, Mass., and it left the city 24 hours before the great fire which entirely destrojed the plant and buildings of the firm. In this pattern a Bourdon gange was cmploged, the moving parts being balanced in accordance with Lane's pitent. The Bourdon tube was hermetically sealed, and the rarying pressure was brought to benr upon the exterior of the tube. This was effected by filling tho gange with glycerine, the external water pressure being carried to tho glycerine throngh an elastic diaplerngm placed in a suitable position on the side or end of the metal jacket. In this arrangement a thin glass orer the dial could be nsed, because the pressure on the exterior was communicated to the interior. Expcriments with this instrument showed that blows on the exterior prodneed inaceuracies in the maximum readings.

Mr. Casella, the well-known instrument maker to the Admirnltr, the Ordnance, \&c., now took the matter up, and sereral instruments wcro made, differing much from my pattern. Ercntualls, however, it ras found expedient to return to an arrangement of the Bourdon tube, and an efficient gorernor for controlling the moving parts and preventing fuctuations and inaccoracies of the masimnm indicator, designed by Mrr. Casella, was embodicd in the instrument, drawings of which are giren in Plate, Figs. 1, 2, 3.

Tho metal case with glass face is nearly filled with a transparcnt and stable fluid, such as glycerine. 'The cylinder at one end of the case contains $\Omega$ loosely fitting piston, clamped to a rod, which is fired to some convenient part of the motion. The hole in the cylindercorer, through which the rod is taken, is mado slightly larger than the rod. The maximam indicator is actuated in one direction only by the projection on the indicating arm, and is set at zero by the set-rod, which passes through a stuffing-box, and is connected to a thumb-screw outside the casc. The screw cap and ring at one end of the case is

1 Read at the erening mecting on Monday, January 29th. Admiral of the Flect Sir Ilenry J. Codrington, K.O.B., in the Chair. 
perforated with a small hole, which gives the salt water free access to the outside of the clastic diaphragm.

The thickness of the glass face is only given in order to guard against its fracture from a blow.

I am assured by Officers, both of the Royal Navy and of the great ocean steamship companies, that a trustworthy sor nding apparatus for navigating purposes (s much required.

'I'he ordinary lead cannot bo relied upon when taking soundings of over 100 fathoms, and not long since I was informed of the following incident, which distinctly prores the assertion.

$A$ large passenger stenmer was making the American const in thick weather, which had prevented any obserration of the sun for several days. The captain stopped his ressel and took a sounding with an ordinary heavy lead. There was apparently no hitch of any kind, and " no bottom at 100 fathoms," induced the captain (a cautions and intelligent officer) to proceed at a fair speed. Shortly afterwards the look-out descried "breakers ahead," and the ship was only stopped just in time to prevent a grent catastrophe. If the sounding had been correct the ship would have been 30 miles from the breakers.

I hare myself witnessed the inaccarate results obtained from thoso sounding apparatus, in which clock-work is drircu by a fan revolving in the water as the lead sinks, and I think it will be safe to assert that the sounding apparatus now before you is much more easily used in rough weather than the apparatus designed by Sir William Thomson, in which a wire rans off $n$ reel which is thrown overboard and foats belind the ressel.

It is not considered that the ingenious bathometer designed by Messrs. Siemens Brothers, and described in the Times of the 28th February, 1876, will obviato the necessity of taking sonndings; but on the contrary, that the chief use of a Sicmens' bathometer will be to indicate vithen it is necessary or advisable to take an accurate sounding.

'The apparatus now before you has been designed in order to enable ressels to take accurate soundings to depths of 180 to 200 fathoms, though, if required, tho sounders may be had to record greater deptbs. It is actuated by the water pressure, which varies directly as the depth. The specific gravity of salt water raries but little in different parts of the world, the differenco between the extremes being less than $1 \frac{1}{2}$ per sent. The average weight of salt water is $6 \pm 1 \mathrm{lbs}$. per cubic foot, and the instruments are graduated to rend to fathoms when submerged in water of the above density.

The apparatus should be used as follows: $-\Lambda$ n ordinary lead is attached 6 feet beluw the loner eye of the instrument, and the end of an ordinary sounding line is rove tlurough the upper eyce. The maximum reader or indicating arm is then placed at zero, by means of tho thumb-screw at the back, and the instrument and lead are thrown orerboard. As soon as a decrease in the tension on the line shorrs that the instrument has reached the bottom, it is again brought to the surface, and the number of fathoms it sank will be recorded by the maximum reader on the dial. The length of the sounding line should not exced the depth to which the instrument is graduated. 
The advantages claimed for this sounding apparatus, are as follows:-

1. That accurate soundings can be taken without entirely stopping a ressel's way, which is sometimes a matter of great difficulty.

2. That under-currents which prevent the line taking a trne rertical direction, do not impair the accuracy of this instrument.

3. That its action being independent of its motion through the water, its accuracy is nol affected by the moving parts being lubricated, either too much or too little, as no Jubrication is required.

The price of the instrument is $10 l$.

The weight of salt water in different parts of the world differs but little.

This is shown in the following table.

Pressures in pounds on the square inch at various depths below the surface at 60 degrees Fahrenheit.

\begin{tabular}{|c|c|c|c|c|}
\hline \multirow{2}{*}{$\begin{array}{l}\text { Depth in } \\
\text { fathoms. }\end{array}$} & \multicolumn{4}{|c|}{ Pressure in pounds on square inch. } \\
\hline & Distilled water. & Baltic. & Atlantic. & Mediterrancan. \\
\hline $\begin{array}{r}24 \\
48 \\
72 \\
96 \\
120 \\
141 \\
168\end{array}$ & $\begin{array}{r}62 \cdot 50 \\
125 \cdot 00 \\
187 \cdot 50 \\
250 \cdot 00 \\
312 \cdot 50 \\
375 \cdot 00 \\
437 \cdot 50\end{array}$ & $\begin{array}{r}63 \cdot 44 \\
126 \cdot 89 \\
190 \cdot 32 \\
253 \cdot 76 \\
317 \cdot 20 \\
380 \cdot 64 \\
441 \cdot 08\end{array}$ & $\begin{array}{r}61 \cdot 25 \\
128 \cdot 50 \\
192 \cdot 75 \\
257 \cdot 00 \\
321 \cdot 25 \\
385 \cdot 50 \\
449 \cdot 75\end{array}$ & $\begin{array}{r}61 \cdot 31 \\
128 \cdot 62 \\
192 \cdot 93 \\
257 \cdot 2 \cdot 4 \\
321 \cdot 55 \\
385 \cdot 56 \\
450 \cdot 17\end{array}$ \\
\hline
\end{tabular}

The effect of temperature on the accuracy of the sounder is in. npprcciable.

This is shown in the following table.

Pressures in pounds on the square inch at 24, fathoms below the surface at various Temperatures.

\begin{tabular}{|c|c|c|c|c|}
\hline $\begin{array}{l}\text { Temperature in } \\
\text { degress Falis. }\end{array}$ & Distilled water. & Baltic. & Atlantic. & Jediternucan. \\
\hline $\begin{array}{l}35^{\circ} \\
40^{\circ} \\
45^{\circ} \\
50^{\circ} \\
55^{\circ} \\
60^{\circ} \\
65^{\circ} \\
70^{\circ} \\
75^{\circ} \\
80^{\circ}\end{array}$ & $\begin{array}{r}62 \cdot 556 \\
.558 \\
.555 \\
.536 \\
.524 \\
.500 \\
\cdot .469 \\
\cdot 434 \\
.394 \\
\cdot 319\end{array}$ & $\begin{array}{r}63 \cdot 490 \\
\cdot 493 \\
.495 \\
\cdot 476 \\
\cdot 461 \\
.440\end{array}$ & $\begin{array}{r}61 \cdot 306 \\
\cdot 303 \\
\cdot 305 \\
\cdot 286 \\
\cdot 274 \\
\cdot 250\end{array}$ & $\begin{array}{r}61 \cdot 366 \\
\cdot 368 \\
\cdot 365 \\
\cdot 316 \\
-334 \\
\cdot 310\end{array}$ \\
\hline
\end{tabular}




\section{BUCKNILL AND GASELLA's PATENT APPARATUS, \&a.}

The Admiralty are now trying one of our sounders, similar to that shown in the Plate, and a foreign Gorernment has also obtained one for trial and experiment.

In ansmer to a qucstion by the Chairman asking if the gauge had been tried, Mr. Casella said that, though only now introduced, he beliered it had been tried at sen, but it certainly had been tested in its manufacture, as be had the means of testing cach gauge in water $\mathrm{kr}$ his hydraulic apparatus, arhich had been expressly arranged to test the compresstoility of thermoneters and rarious substances in water at any depth. The capabilitics of cach gauge were thus perfectly knotm at the time of manufacture. 'This mode of testing was quite open for the inspection of any one taling interest in the matter. 